\title{
Leveraging endogenous barley enzymes to turn lactose-containing dairy by-products into fermentable adjuncts for Saccharomyces cerevisiae-based ethanol fermentations
}

M. R. Lawton and S. D. Alcaine*

Department of Food Science, Cornell University, Ithaca, NY 14853

\section{ABSTRACT}

Acid whey, a by-product of strained yogurt production, represents a disposal challenge for the dairy industry. Utilization schemes are currently limited; however, acid whey contains valuable components that could be used to create value-added products. One potential scheme would be the fermentation of acid whey into an alcoholic beverage. Sour beers are gaining popularity and acid whey, which is sour to begin with, could provide a new product opportunity. However, the main sugar of acid whey, lactose, cannot be fermented by the traditional brewer's yeast, Saccharomyces cerevisiae. It has been reported that barley contains enzymes capable of hydrolyzing lactose to glucose and galactose, which are fermentable by $S$. cerevisiae. We investigated whether a barley-based mash resulted in detectable hydrolysis of lactose into sugars fermentable by $S$. cerevisiae. We demonstrated the ability to hydrolyze lactose in acid whey using a barley-based mash, resulting in the average release of $3.70 \mathrm{~g} / \mathrm{L}$ of glucose. Additionally, the subsequent liquid was fermented by $S$. cerevisiae to an average ethanol concentration of $3.23 \%$ alcohol by volume. This work demonstrates the ability to hydrolyze the lactose in acid whey using barley and the opportunity to use acid whey as a fermentable sugar source in beer production.

Key words: acid whey, by-product, value-added, dairy beverage, beer

\section{INTRODUCTION}

Acid whey is a byproduct of strained-yogurt products, such as Greek yogurt and skyr, and represents a significant disposal challenge for the dairy industry. Estimates are that over 2.3 million tonnes of Greek yogurt acid whey are produced per year (Erickson, 2017). The main component of acid whey is lactose, a

Received August 23, 2018.

Accepted November 5, 2018.

*Corresponding author: alcaine@cornell.edu disaccharide made up of glucose and galactose linked by a $\beta-1,4$ glyosidic bond, which is present at $\sim 3.0$ to $6.0 \%$ (Smithers, 2015). The high-heat treatment of the milk in yogurt production, which is done to denature the whey protein and capture it in the yogurt body, thus improving consistency (Chandan and Kilara, 2006), results in very low residual protein. Acid whey contains $\sim 6.4 \mathrm{~g} / \mathrm{L}$ of lactic acid (Bansal and Bhandari, 2016), resulting in a lower $\mathrm{pH}$ and increased mineral solubility; thus, it is high in minerals, including calcium $(1.23 \mathrm{~g} / \mathrm{L})$, magnesium $(0.11 \mathrm{~g} / \mathrm{L})$, and phosphate $(2.0$ $\mathrm{g} / \mathrm{L}$ ), in comparison to sweet whey (Bansal and Bhandari, 2016; Smith et al., 2016). All these components contribute to a significant biochemical oxygen demand of 30 to $50 \mathrm{~g} / \mathrm{L}$ and a chemical oxygen demand of 60 to $80 \mathrm{~g} / \mathrm{L}$, making disposal environmentally problematic (Domingues et al., 1999). The high lactic acid content of acid whey makes its utilization in dry powders, which is common for other dairy by-products, difficult due to the effect on crystallization (Bansal and Bhandari, 2016). Currently, the main acid whey utilization schemes involve (1) direct application to agricultural fields; (2) use in animal feed; and (3) use as a feed to anaerobic digestors and waste water-treatment sites (Mawson, 1994; Prazeres et al., 2012). These alternatives for acid whey utilization, however, pose an economic burden, as little value is returned from them and producers are typically responsible for the transportation costs. Thus, additional venues for utilization of acid whey are needed.

Incorporation of acid whey into the production of alcoholic beverages, such as beer, represents a possible value-added outlet. Sour beers, those produced with lactic acid bacteria in the mash to drop the $\mathrm{pH}$ of the wort before fermentation, are gaining popularity, and interest exists in improving their production process (Osburn et al., 2018). Acid whey could be used to replace some or all of the water introduced during the mash process, thus providing the sour base. Some brewers are known to use Greek yogurt as the source of the lactic acid bacterial cultures containing Lactobacillus bulgaricus and Streptococcus thermophilus (Burke et al., 
2015); thus, utilizing acid whey from strained yogurt could simplify this process.

One potential drawback of utilizing acid whey in the brewing process is the remaining lactose. Traditional brewer's yeast, Saccharomyces cerevisiae, cannot use lactose (Oleary et al., 1977b). Some non-Saccharomyces yeast strains, such as Kluyveromyces marxianus (Kosikowski and Wzorek, 1977; Mawson, 1994; Risner et al., 2018), have been used to convert lactose to ethanol, but they are not used in beer brewing and are considered spoilage organisms in wines, potentially producing undesirable off-notes. Another option is the addition of lactases to break down the lactose in glucose and galactose, that can then be used by $S$. cerevisiae (Oleary et al., 1977a,b; Mawson, 1994). It is the latter avenue, the use of enzymes to hydrolyze lactose in simple sugars for fermentation, that we explored in the current study.

Enzymes are an added cost for production. In beer production, malted barley not only provides the starch that will be converted into ethanol, but also provides the enzymes, $\alpha$ - and $\beta$-amylase, that breakdown these complex starches into simple sugars for $S$. cerevisiae to ferment into ethanol (MacGregor et al., 1999). Though not evaluated in beer production, $\beta$-galactosidase ( $\boldsymbol{\beta}$-gal) and $\beta$-glucosidase ( $\boldsymbol{\beta}$-gluc) endogenous to barley with activity against lactose have been identified (Simos and Georgatsos, 1988). The $\beta$-gluc has been shown to develop during barley seed maturation, and both enzymes remain active during germination (Giannakouros et al., 1991; Simos et al., 1994). The barley $\beta$-gal is reported to have optimum activity around $\mathrm{pH}$ 4.0 and the optimal $\mathrm{pH}$ of the $\beta$-gluc is reported as 4.5 to 5.0 (Simos and Georgatsos, 1988). These optimums fall within the $\mathrm{pH}$ of acid whey, which has been reported to range from 3.5 to 5.1 (Smithers, 2015). In this study, we aimed to (1) evaluate whether $\beta$-glycosidases present in barley, and related grains, are sufficient to hydrolyze lactose in a mash; (2) evaluate lactose hydrolysis in an acid whey-based raw barley mash; and (3) demonstrate that ethanol can be produced from acid whey using a barley mash. Hydrolysis of lactose into glucose and galactose using barley $\beta$-glycosidases in a mash would allow for the incorporation of acid whey as both a natural acidulant and as fermentable adjunct sugar source in beer production.

\section{MATERIALS AND METHODS}

\section{Materials}

Barley grits (meal) and whole-grain cracked rye were purchased from Bob's Red Mill Natural Foods (Mil- waukie, OR). Rahr Unmalted Wheat was purchased from Northern Brewer (Roseville, MN). Barley meal was used as purchased, and rye and wheat were ground in a coffee grinder for 30 one-second pulses. D-Lactose was purchased from Sigma Aldrich (St. Louis, MO). D-Galactose was purchased from VWR (Radnor, PA). Acid whey was obtained from a local Greek yogurt manufacturer in upstate New York. Yeast used in the study was Saccharomyces cerevisiae var. Bayanus (Uvaferm 43) purchased from Lallemand (Ontario, Canada). Reagents and equipment for the enzymatic glucose assay were purchased from Randox Laboratories Ltd. (Kearneysville, WV).

\section{Unmalted Barley Mash with Lactose}

A mash containing $250 \mathrm{~mL}$ of $10 \%$ (wt/wt) lactose solution and $65.9 \mathrm{~g}$ of barley meal was shaken constantly at 40 or $50^{\circ} \mathrm{C}$ for $3 \mathrm{~h}$. A control mash consisting of barley meal and water, with no source of lactose added, was used to determine the amount of free glucose in the grain or released from barley amylase activity. Samples were taken at $0,10,60,120$, and $180 \mathrm{~min}$ and heated to $70^{\circ} \mathrm{C}$ for 5 min to stop further enzyme activity. Samples were then centrifuged at $9,615 \times g$ for 5 min at $25^{\circ} \mathrm{C}$ and the supernatant was collected as the wort for glucose analysis.

\section{Mash with Unmalted Wheat and Rye}

A mash containing $250 \mathrm{~mL}$ of $10 \%$ (wt/wt) lactose solution and $65.9 \mathrm{~g}$ of rye or wheat was shaken constantly at $40^{\circ} \mathrm{C}$ for $3 \mathrm{~h}$. A control mash consisting of $250 \mathrm{~mL}$ of water and $65.9 \mathrm{~g}$ of rye or wheat with no source of lactose added was used. Samples were taken at $0,10,60,120$, and $180 \mathrm{~min}$ and heated to $70^{\circ} \mathrm{C}$ for $5 \mathrm{~min}$ to stop further enzyme activity. Samples were then centrifuged at $9,615 \times g$ for 5 min at $25^{\circ} \mathrm{C}$ and the supernatant was collected as the wort for glucose analysis.

\section{Mash with Acid Whey}

A mash containing $250 \mathrm{~mL}$ of acid whey and $65.9 \mathrm{~g}$ of barley meal was shaken constantly at 40 or $50^{\circ} \mathrm{C}$ for 3 h. A control mash consisting of barley meal and water, with no source of lactose added, was used to determine the amount of free glucose in the grain or released from barley amylase activity. Samples were taken at 0, 10, 60, 120 , and $180 \mathrm{~min}$ and heated to $70^{\circ} \mathrm{C}$ for $5 \mathrm{~min}$ to stop further enzyme activity. Samples were then centrifuged at $9,615 \times g$ for $5 \mathrm{~min}$ at $25^{\circ} \mathrm{C}$ and the supernatant was collected as the wort for glucose analysis. 


\section{Enzyme Deactivation}

Barley meal was autoclaved at $121^{\circ} \mathrm{C}$ for 20 min to deactivate any lactose-hydrolyzing enzymes. This barley $(65.9 \mathrm{~g})$ was then used in a mash containing 250 $\mathrm{mL}$ of $10 \%$ (wt/wt) lactose solution. A control mash consisted of $65.9 \mathrm{~g}$ of untreated barley meal and $10 \%$ (wt/wt) lactose solution. Samples were taken at 0 and $180 \mathrm{~min}$ and heated to $70^{\circ} \mathrm{C}$ to stop further enzyme activity. Samples were then centrifuged at $9,615 \times g$ for 5 min at $25^{\circ} \mathrm{C}$ and the supernatant was collected as the wort for glucose analysis.

\section{Fermentation}

A mash was prepared from a $10 \%$ (wt/wt) lactose solution or acid whey and barley meal. The mash was shaken constantly at $50^{\circ} \mathrm{C}$ for $8 \mathrm{~h}$. The controls consisted of a mash containing water and barley meal that incubated for $8 \mathrm{~h}$ or a mash containing a 10\% (wt/wt) lactose solution and barley meal that did not incubate. Without filtering, each mash was inoculated with $0.25 \mathrm{~g}$ of $S$. cerevisiae and incubated at $25^{\circ} \mathrm{C}$ for $14 \mathrm{~d}$. Samples for glucose and ethanol analysis were taken before and after fermentation.

\section{Glucose, Ethanol, and Titratable Acidity Analysis}

Levels of glucose in the wort samples were analyzed with the Randox Glucose/Fructose UV Method on the Randox Monaco Analyzer (Randox Laboratories Ltd.). Samples were analyzed according to the manufacturer's instructions (http://www.randoxonlinestore .com/Reagents/Glucose-fructose-assay-p-8293). Levels of ethanol in the samples were analyzed via HPLC with a Rezex ROA-Organic Acid $\mathrm{H}+(8 \%)$ column (Phenomenex, Torrance, CA) and a refractive index detector.

\section{Statistical Analysis}

Triplicate samples were taken for analysis at each time point and each experiment was repeated 3 times on separate occasions. A Student's $t$-test was conducted to determine differences between mean glucose levels in the treatment and the control at 0 and 180 min during mash experiments or 0 and $14 \mathrm{~d}$ for fermentation experiments.

\section{RESULTS AND DISCUSSION}

\section{Lactose Hydrolysis in a Raw Barley Mash}

Lactose is not considered an adjunct sugar by brewers because it is not hydrolyzed during the mash and is subsequently unfermentable by $S$. cerevisiae. Our first question was whether we could detect $\beta$-gal $/ \beta$-gluc activity through an increase in glucose levels during a mash. In a typical mash, $\alpha$-amylase is responsible for glucose release from barley starch molecules, but its optimum temperature is greater than $60^{\circ} \mathrm{C}$ (Bertoft et al., 1984), well above the reported optimum of $40^{\circ} \mathrm{C}$ (Simos and Georgatsos, 1988) of the $\beta$-gal $/ \beta$-gluc. Initial studies with malted barley mash at $40^{\circ} \mathrm{C}$ (data not shown) showed no increase in glucose levels. We suspect that the high temperatures during the kilning of malted barley heat-inactivate the $\beta$-gal and $\beta$-gluc enzymes. Base malts are typically produced by initially drying the germinated barley at temperatures of 40 to $50^{\circ} \mathrm{C}$ and subsequently heating the malt to 80 to $85^{\circ} \mathrm{C}$ (Kunze, 1999). The lactose-hydrolyzing enzymes that are associated with barley are reported to lose $70 \%$ of activity after $10 \mathrm{~min}$ at $60^{\circ} \mathrm{C}$ (Simos and Georgatsos, 1988), which is well below typical malting temperatures. As these lactose-hydrolyzing enzymes were characterized in unmalted barley (Simos and Georgatsos, 1988), we proceeded to do a mash solely with barley meal. Alpha amylase activity is quite low in unmalted barley (Georg-Kraemer et al., 2001); thus, background glucose levels would be lower in the mash and beers produced with raw barley. Raw barley as a portion (Hudson et al., 1963; Koszyk and Lewis, 1977) or complete (Enevoldsen, 1970) makeup of the grain in a mash has been reported, so its use by a brewer would be feasible for the production of a beer. We mashed $100 \%$ barley meal at 40 and $50^{\circ} \mathrm{C}$ and monitored glucose levels over time via an enzymatic assay to detect any lactose hydrolysis. These values were compared with the control treatment, with no added lactose to account for any potential background glucose released from the barley. As seen in Figure 1, at both 40 and $50^{\circ} \mathrm{C}$ an increase in glucose concentrations over time occurred. At $3 \mathrm{~h}$, the concentration of glucose in the sample was higher $(P<0.05)$ than the control for both temperatures. The concentration of glucose at $3 \mathrm{~h}$ in the $50^{\circ} \mathrm{C}$ experiment reached an average of $10.16 \mathrm{~g} / \mathrm{L}$ and was higher $(P<$ $0.05)$ than at $40^{\circ} \mathrm{C}$. It is interesting that higher activity was observed at $50^{\circ} \mathrm{C}$, a temperature greater than the $40^{\circ} \mathrm{C}$ optimum reported (Simos and Georgatsos, 1988). Enzyme levels and activity have been shown to vary between barley varieties (Gunkel et al., 2002). Whereas the variety of the barley used in these experiments was not reported by the manufacturer, it was sourced from different continents more than 25 yr later than the original studies by Simos and Georgatsos (1988), and thus it is likely that our barley is not the same variety as in their study. Furthermore, Simos and Georgatsos (1988) did not look at the activity of these enzymes under mashing conditions, where the viscosity of the 
mash may impart some degree of heat protection to the enzymes. These 2 differences, barley variety and experimental conditions, likely explain the observed difference in $\beta$-gal $/ \beta$-gluc activity. Future research into the differences in $\beta$-gal $/ \beta$-gluc levels and activity between modern barley varieties would be an important next step in implementation and optimization of this process.

\section{Limited Lactose Hydrolysis in Other Raw Grains}

Gelman (1969) also reported isolating lactosehydrolyzing enzymes from wheat and rye, as well as barley. As in raw barley, both raw wheat (Depraetere et al., 2004) and raw rye (Koszyk and Lewis, 1977), have been used as adjunct grains in brewing. We were curious whether these raw grains could also be used as an enzyme source for lactose hydrolysis in a mash. We mashed either wheat or rye in a $10 \%$ (wt/wt) lactose solution at $40^{\circ} \mathrm{C}$ for $3 \mathrm{~h}$. Low levels of lactose hydrolysis were observed over time (Figure 2). In the rye mash, glucose concentrations reached $3.17 \mathrm{~g} / \mathrm{L}$ after
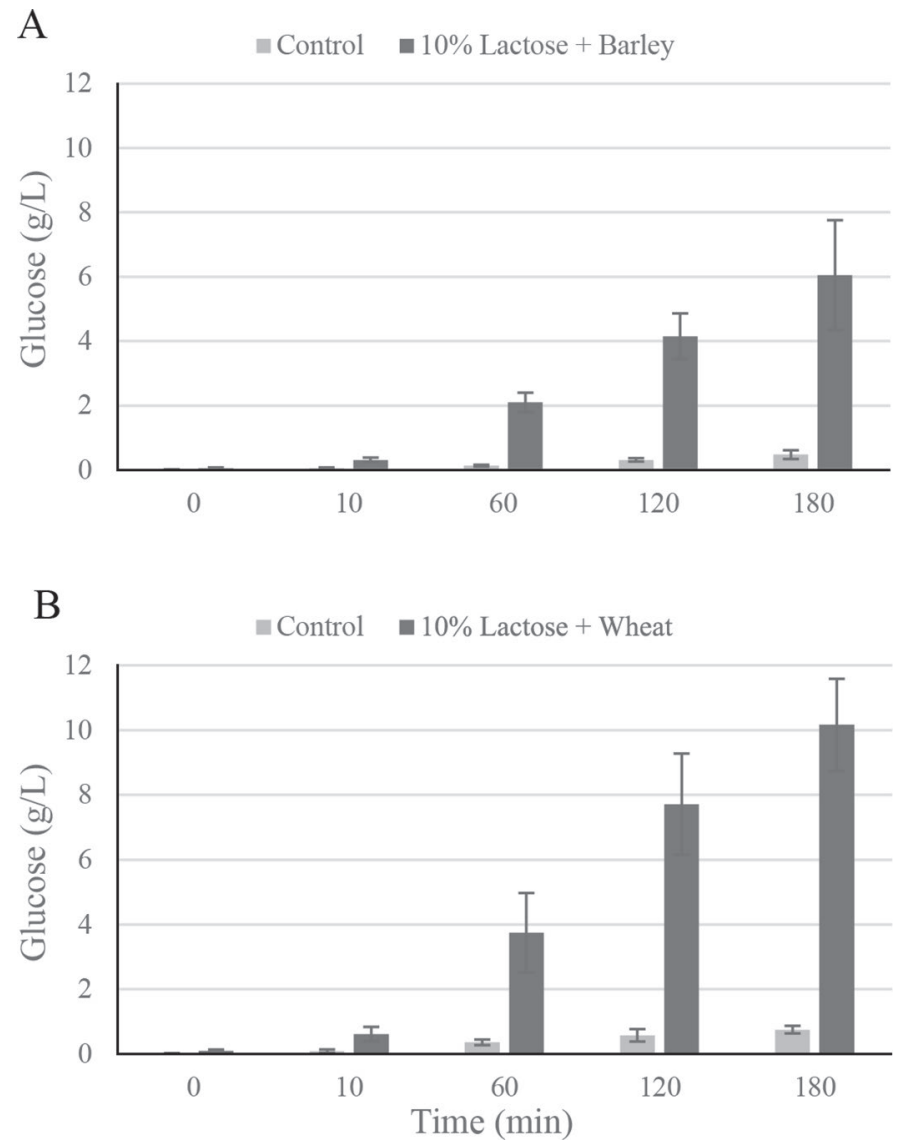

Figure 1. Hydrolysis of $10 \%$ (wt/wt) lactose solution by barley over time at $40^{\circ} \mathrm{C}(\mathrm{A})$ and $50^{\circ} \mathrm{C}(\mathrm{B})$. Error bars represent $\pm 1 \mathrm{SD}$.
$3 \mathrm{~h}$ and, in the wheat mash, glucose concentrations reached $4.10 \mathrm{~g} / \mathrm{L}$ after $3 \mathrm{~h}$. Final glucose levels in rye were significantly higher $(P<0.05)$ than in the control, whereas the final glucose levels in the wheat were not significantly higher than the control $(P>0.05)$. In both cases there appeared to be much more pronounced background glucose, as seen in the control, compared with the raw barley, and the final glucose levels were less than those observed in the raw barley mash at the same temperature. We thus decided to continue further evaluations with only the raw barley.

\section{Heat Inactivation of Lactose-Hydrolyzing Enzymes in Raw Barley}

We had originally speculated that we would not observe lactose hydrolysis in the early malted barley experiments due to heat inactivation of the enzymes during the malting. The drying step during malting, known as kilning, can reach temperatures in excess of $200^{\circ} \mathrm{C}$. To confirm that a heat-sensitive enzyme was responsible for the observed hydrolysis in the raw

A

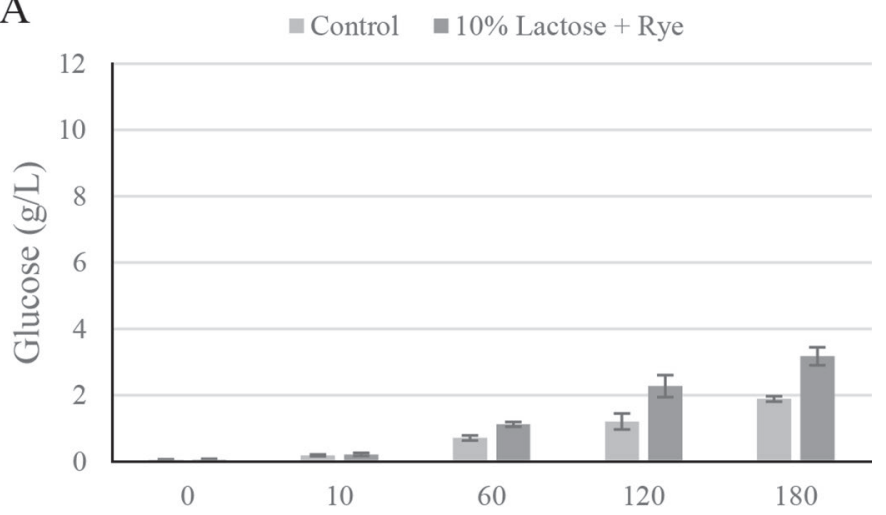

B

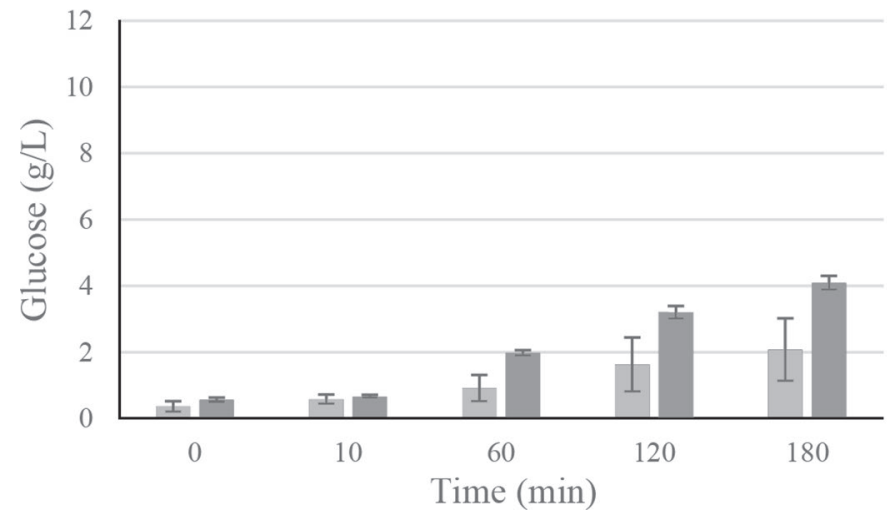

Figure 2. Hydrolysis of $10 \%$ (wt/wt) lactose solution over time by rye $(\mathrm{A})$ and wheat $(\mathrm{B})$ at $50^{\circ} \mathrm{C}$. Error bars represent $\pm 1 \mathrm{SD}$. 
barley mash, we autoclaved the barley meal at $121^{\circ} \mathrm{C}$ for $20 \mathrm{~min}$. We then proceeded to compare 3 -h mash glucose levels between the heat-treated barley meal and a control, non-heat-treated barley meal (Figure $3)$. No increase in glucose concentration over time was detected when the autoclaved barley was incubated in a mash with $10 \%$ (wt/wt) lactose solution, where we saw a final level of $7.76 \mathrm{~g} / \mathrm{L}$ of glucose detected in the control. This supports the claim that a heat-sensitive enzyme is responsible for lactose hydrolysis in the raw barley mash. Germination is the first step in malting barley, resulting in green malt, and research indicates that both $\beta$-gal/ $\beta$-gluc are present during this step (Simos et al., 1994). Future work, confirming lactose hydrolysis in green malt, and investigating when in the subsequent malting process and at what temperature the enzymes are inactivated could result in a novel malting regimen that enables the production of barley malt that possesses high levels of both lactose- and starch-hydrolyzing enzymes.

\section{Hydrolysis of Acid Whey-Derived Lactose in a Raw Barley Mash}

In the production of sour beers, acid whey can potentially act as a natural acidulant and as a fermentable sugar source. Acid whey typically has a $\mathrm{pH}<4.5$, a lactose content of 3.0 to $3.5 \%$, and calcium content greater than $1.2 \mathrm{mg} / \mathrm{g}$ (Menchik et al., 2018), which is in contrast to our initial mash containing $10 \%$ lactose and no added calcium. These factors, $\mathrm{pH}$, mineral content, and lactose concentration, could all affect enzyme activity. To evaluate the potential of acid whey in this process, we mashed acid whey containing raw barley at both 40 and $50^{\circ} \mathrm{C}$ and measured glucose levels over time. These values were compared with the control treat-

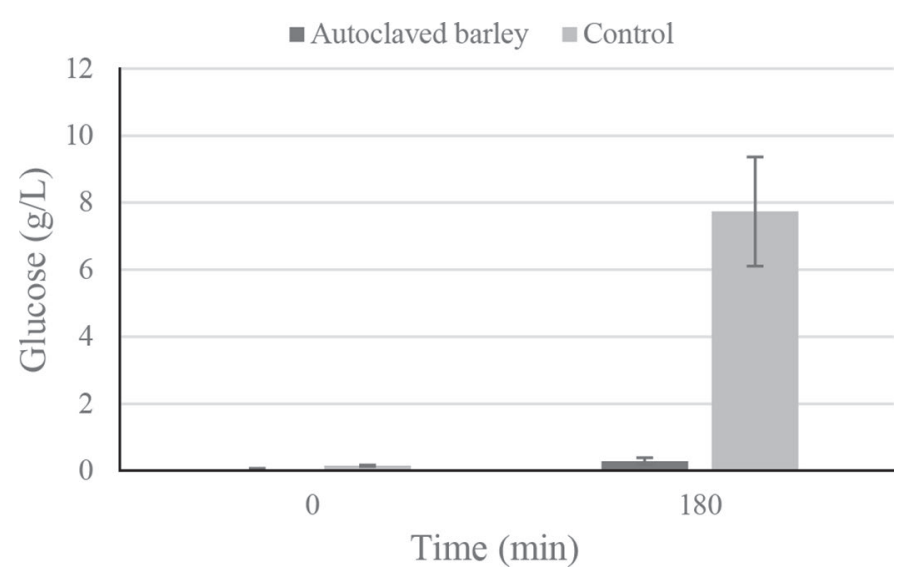

Figure 3. Deactivation of lactose-hydrolyzing enzymes after autoclaving at $121^{\circ} \mathrm{C}$ for $20 \mathrm{~min}$. Error bars represent $\pm 1 \mathrm{SD}$. ment, which contained no added lactose. As seen in Figure 4 , at both 40 and $50^{\circ} \mathrm{C}$ there was an increase in glucose levels over time. At $3 \mathrm{~h}$ for both temperatures, the concentration of glucose in the sample was higher $(P<0.05)$ than the control. At $50^{\circ} \mathrm{C}$, the glucose levels reached on average $4.70 \mathrm{~g} / \mathrm{L}$ after $3 \mathrm{~h}$. We found no difference $(P>0.05)$ in glucose concentrations between 40 and $50^{\circ} \mathrm{C}$. The glucose levels were less than those observed with the mash containing $10 \%$ lactose, but still showed that hydrolysis of lactose via a raw barley mash is possible and that acid whey could serve as both a fermentable adjunct sugar source in beer production.

\section{Ethanol from Raw Barley Hydrolyzed Lactose}

Saccharomyces cerevisiae can use glucose and galactose, once released from lactose, in the production of ethanol, though galactose is not used as efficiently as glucose in this metabolic process (Lee et al., 2011). We wanted to confirm that ethanol could successfully be produced by $S$. cerevisiae from a raw barley mash containing lactose, either added directly or from acid

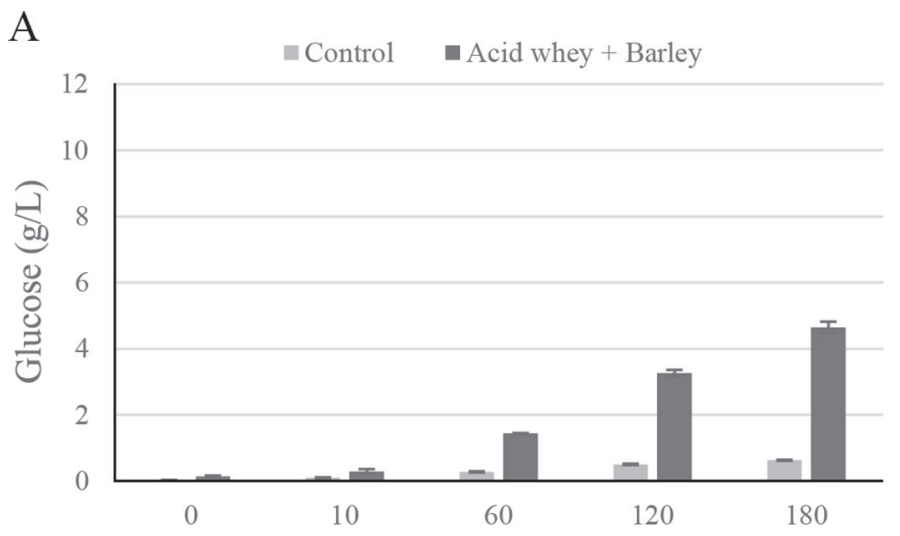

B

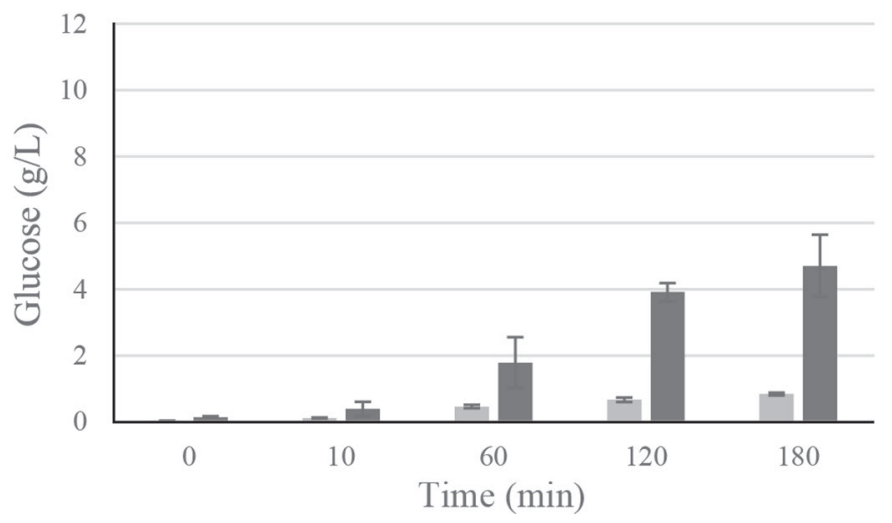

Figure 4. Hydrolysis of lactose by barley in acid whey over time at $40^{\circ} \mathrm{C}(\mathrm{A})$ and $50^{\circ} \mathrm{C}(\mathrm{B})$. Error bars represent $\pm 1 \mathrm{SD}$. 
whey. We carried out (1) a control 8-h mash $\left(50^{\circ} \mathrm{C}\right)$ with barley meal and no added lactose; (2) an 8-h mash $\left(50^{\circ} \mathrm{C}\right)$ with barley meal and acid whey as the lactose source; (3) an 8 -h mash $\left(50^{\circ} \mathrm{C}\right)$ with barley meal and a $10 \%$ (wt/wt) lactose solution; and (4) barley meal with $10 \%$ (wt/wt) lactose solution that was immediately fermented with no mash at $50^{\circ} \mathrm{C}$. Our expectation was that alcohol production would be observed with the mashes containing lactose, and minimal alcohol production would be observed in the control mash and in the mixture that did not incubate at $50^{\circ} \mathrm{C}$, as there would be low background glucose and without a mash there would not have been the conditions for lactose hydrolysis. Indeed, after $14 \mathrm{~d}$ of fermentation, the barley mash containing $10 \%$ (wt/wt) lactose reached an ethanol concentration of on average $5.82 \%$ alcohol by volume and the mash containing acid whey reached an ethanol concentration of on average $3.23 \%$ alcohol by volume, as seen in Figure 5. The control mash, with no added lactose, only reach an ethanol concentration of on average $1.06 \%$ alcohol by volume after $14 \mathrm{~d}$. These results confirm that lactose and acid whey, and potentially other lactose-containing dairy by-products, could be used as fermentable adjunct sugar in beer production if the mash includes raw barley and is held for sufficient time and temperature for lactose hydrolysis to occur.

Interestingly, the fermentation of the $10 \%$ (wt/wt) lactose solution and barley meal, which did not undergo a mash step, reached an average ethanol concentration of $3.37 \%$ alcohol by volume, which was unexpected. After the mash, no heat inactivation step occurred, so this result suggests that although the fermentation

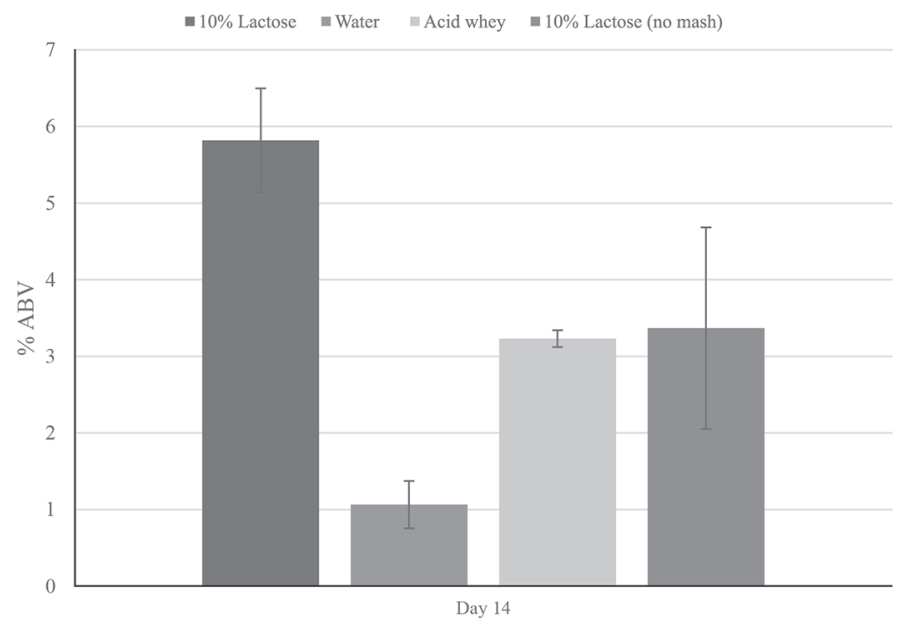

Figure 5. Final ethanol concentration (\% alcohol by volume; ABV) from barley-hydrolyzed lactose fermented with Saccharomyces cerevisiae after $14 \mathrm{~d}$. Error bars represent $\pm 1 \mathrm{SD}$. temperature of $25^{\circ} \mathrm{C}$ was well below the optimum for the $\beta$-gal/ $\beta$-gluc, it was sufficient for some enzymatic activity resulting in lactose hydrolysis and subsequent fermentation by $S$. cerevisiae. Whereas fermenting on grains is not as common in beer production as it is in distilled spirit production, this result indicates that adding raw barley to the fermentation tank, as is done with many fruits added to beers, could represent another method for hydrolyzing lactose into a fermentable sugar for ethanol production.

\section{CONCLUSIONS}

In this work, we investigated the lactose-hydrolyzing activity of barley meal in a lactose solution and acid whey. Analysis of glucose levels in lactose-supplemented barley meal mash showed increasing concentration over time, indicating lactose hydrolysis. Supplementation of mash with $10 \%$ (wt/wt) lactose led to glucose levels of $10.16 \mathrm{~g} / \mathrm{L}$, on average, after $3 \mathrm{~h}$ at $50^{\circ} \mathrm{C}$ and lower levels at $40^{\circ} \mathrm{C}$. The acid whey mash took place at 40 or $50^{\circ} \mathrm{C}$ to retain the activity of the lactose-hydrolyzing enzymes, which were deactivated after autoclaving at $121^{\circ} \mathrm{C}$. Lower lactose-hydrolyzing activity was seen in the other grains; namely, rye and wheat. Furthermore, the use of acid whey, with a lactose concentration of $\sim 33 \mathrm{~g} / \mathrm{L}$, in a mash resulted in glucose concentrations of $4.70 \mathrm{~g} / \mathrm{L}$ after $3 \mathrm{~h}$. Additionally, a yeast fermentation of acid whey and barley meal mashed for $8 \mathrm{~h}$ produced ethanol concentrations of, on average, $3.23 \%$ alcohol by volume and $3.37 \%$ alcohol by volume when no mash step occurred, indicating that an alcoholic beverage can be produced directly from acid whey without supplementation of sugar for fermentation. This provides an opportunity to create new beers and beer styles with acid whey as a base for fermentation.

\section{ACKNOWLEDGMENTS}

This project was funded by the New York State Department of Environmental Conservation (Albany), Project Number 76370/A001. The authors thank the New York State Wine Analytical Lab (Geneva, NY) for help with analysis of samples.

\section{REFERENCES}

Bansal, N., and B. Bhandari. 2016. Functional milk proteins: Production and utilization -Whey-based ingredients. Pages 67-98 in Advanced Dairy Chemistry: Volume 1B: Proteins: Applied Aspects. P. L. H. McSweeney and J. A. O'Mahony, ed. Springer New York, New York, NY.

Bertoft, E., C. Andtfolk, and S. E. Kulp. 1984. Effect of pH, temperature, and calcium ions on barley malt $\alpha$-amylase isoenzymes. J. Inst. Brew. 90:298-302. 
Burke, S., B. Edmunds, and B. Love. 2015. Kettle souring: Three brewers talk methods and practices. Page 31. Conf. Prog. Craft Brewers Conf. BrewExpo America, Portland, OR.

Chandan, R. C., and A. Kilara, ed. 2006. Manufacturing Yogurt and Fermented Milks. 1st ed. Blackwell Pub., Ames, IA.

Depraetere, S. A., F. Delvaux, S. Coghe, and F. R. Delvaux. 2004. Wheat variety and barley malt properties: Influence on haze intensity and foam stability of wheat beer. J. Inst. Brew. 110:200-206.

Domingues, L., M. M. Dantas, N. Lima, and J. A. Teixeira. 1999 Continuous ethanol fermentation of lactose by a recombinant flocculating Saccharomyces cerevisiae strain. Biotechnol. Bioeng. 64:692-697.

Enevoldsen, B. S. 1970. I. Conditions of mashing and carbohydrate composition of the wort. J. Inst. Brew. 76:546-552.

Erickson, B. E. 2017. Acid whey: Is the waste product an untapped goldmine? Pages 26-30 in Chemical \& Engineering News. Vol. 95. American Chemical Society, Washington, DC.

Gelman, A. L. 1969. Some beta-glycosidases in barley and other cereals. J. Sci. Food Agric. 20:209-212.

Georg-Kraemer, J., E. Mundstock, and S. Cavalli-Molina. 2001. Developmental expression of amylases during barley malting. J. Cereal Sci. 33:279-288.

Giannakouros, T., A. Karagiorgos, and G. Simos. 1991. Expression of beta-galactosidase multiple forms during barley (Hordeum vulgare) seed germination - Separation and characterization of enzyme isoforms. Physiol. Plant. 82:413-418.

Gunkel, J., M. Voetz, and F. Rath. 2002. Effect of the malting barley variety (Hordeum vulgare L) on fermentability. J. Inst. Brew. 108:355-361.

Hudson, J., I. MacWilliam, and S. Birtwistle. 1963. Beer from unmalted barley. J. Inst. Brew. 69:308-309.

Kosikowski, F. V., and W. Wzorek. 1977. Whey wine from concentrates of reconstituted acid whey powder. J. Dairy Sci. 60:19821986.

Koszyk, P., and M. Lewis. 1977. Unmalted grains as maltsters' adjuvant and brewers' adjunct. J. Am. Soc. Brew. Chem. 35:77-81.

Kunze, W. 1999. Malt kilning. Pages 143-145 in Technology Brewing and Malting. 2nd Rev. Intl. Ed. VLB, Berlin, Germany.

Lee, K. S., M. E. Hong, S. C. Jung, S. J. Ha, B. J. Yu, H. M. Koo, S. M. Park, J. H. Seo, D. H. Kweon, and J. C. Park. 2011. Improved galactose fermentation of Saccharomyces cerevisiae through inverse metabolic engineering. Biotechnol. Bioeng. 108:621-631.

MacGregor, A., S. Bazin, L. Macri, and J. Babb. 1999. Modelling the contribution of alpha-amylase, beta-amylase and limit dextrinase to starch degradation during mashing. J. Cereal Sci. 29:161-169.

Mawson, A. J. 1994. Bioconversions for whey utilization and waste abatement. Bioresour. Technol. 47:195-203.

Menchik, P., T. J. Zuber, A. Zuber, and C. Moraru. 2018. The acid whey conundrum. Pages 41-43 in Dairy Foods Magazine. Vol. 119. BNP Media, Troy, MI.

Oleary, V. S., R. Green, B. C. Sullivan, and V. H. Holsinger. 1977a. Alcohol production by selected yeast strains in lactase-hydrolyzed acid whey. Biotechnol. Bioeng. 19:1019-1035.

Oleary, V. S., C. Sutton, M. Bencivengo, B. Sullivan, and V. H. Holsinger. 1977b. Influence of lactose hydrolysis and solids concentration on alcohol production by yeast in acid whey ultrafiltrate. Biotechnol. Bioeng. 19:1689-1702.

Osburn, K., J. Amaral, S. R. Metcalf, D. M. Nickens, C. M. Rogers, C. Sausen, R. Caputo, J. Miller, H. Li, J. M. Tennessen, and M. L. Bochman. 2018. Primary souring: A novel bacteria-free method for sour beer production. Food Microbiol. 70:76-84.

Prazeres, A. R., F. Carvalho, and J. Rivas. 2012. Cheese whey management: A review. J. Environ. Manage. 110:48-68.

Risner, D., A. Shayevitz, K. Haapala, L. Meunier-Goddik, and P. Hughes. 2018. Fermentation and distillation of cheese whey: Carbon dioxide-equivalent emissions and water use in the production of whey spirits and white whiskey. J. Dairy Sci. 101:2963-2973.

Simos, G., and J. G. Georgatsos. 1988. Lactose-hydrolyzing beta-glycosidases of barley meal. Biochim. Biophys. Acta 967:17-24.

Simos, G., C. A. Panagiotidis, A. Skoumbas, D. Choli, C. Ouzounis, and J. G. Georgatsos. 1994. Barley beta-glucosidase - Expression during seed germination and maturation and partial amino acid sequences. Biochim. Biophys. Acta 1199:52-58.

Smith, S., T. J. Smith, and M. A. Drake. 2016. Short communication: Flavor and flavor stability of cheese, rennet, and acid wheys. J. Dairy Sci. 99:3434-3444.

Smithers, G. W. 2015. Whey-ing up the options-Yesterday, today and tomorrow. Int. Dairy J. 48:2-14. 